\title{
Correction to: Does a Screening Trial for Spinal Cord Stimulation in Patients with Chronic Pain of Neuropathic Origin have Clinical Utility and Cost-Effectiveness? (TRIAL-STIM Study): study protocol for a randomised controlled trial
}

Sam Eldabe ${ }^{1}$, Ashish Gulve ${ }^{1}$, Simon Thomson ${ }^{2}$, Ganesan Baranidharan ${ }^{3}$, Rui Duarte ${ }^{4 *}$, Susan Jowett ${ }^{5}$, Harbinder Sandhu ${ }^{6}$, Raymond Chadwick, Morag Brookes ${ }^{1}$, Anisah Tariq ${ }^{1}$, Jenny Earle ${ }^{8}$, Jill Bell ${ }^{8}$, Anu Kansal ${ }^{1}$, Shelley Rhodes ${ }^{9}$ and Rod S. Taylor ${ }^{9}$

Correction to: Trials (2018) 19: 633

https://doi.org/10.1186/s13063-018-2993-9

Following publication of the original article [1], we have been notified that the final specification of randomisation implemented in the study is slightly different to that stated in the protocol and needs to be corrected as follows:

- Allocation will be stratified by centre and minimised on patient age ( $\geq 65$ or $<65$ years), gender, and presence of FBSS or not

\section{Author details}

${ }^{1}$ The James Cook University Hospital, Middlesbrough, UK. ${ }^{2}$ Basildon and Thurrock University Hospitals, Basildon, UK. ${ }^{3}$ Leeds Teaching Hospitals, Leeds, UK. ${ }^{4}$ University of Liverpool, Liverpool, UK. ${ }^{5}$ University of Birmingham, Birmingham, UK. ${ }^{6}$ University of Warwick, Warwick, UK. ${ }^{7}$ University of Teesside, Middlesbrough, UK. ${ }^{8}$ Patient and Public Involvement Representatives, Middlesbrough, UK. ${ }^{9}$ University of Exeter, Exeter, UK.

Published online: 28 October 2019

\section{Reference}

1. Eldabe, et al. Does a Screening Trial for Spinal Cord Stimulation in Patients with Chronic Pain of Neuropathic Origin have Clinical Utility and CostEffectiveness? (TRIAL-STIM Study): study protocol for a randomised controlled trial. 2018, 2018;19:633. https://doi.org/10.1186/s13063-018-2993-9.

* Correspondence: rui.duarte@liverpool.ac.uk

${ }^{4}$ University of Liverpool, Liverpool, UK

Full list of author information is available at the end of the article

(c) The Author(s). 2019 Open Access This article is distributed under the terms of the Creative Commons Attribution 4.0 International License (http://creativecommons.org/licenses/by/4.0/), which permits unrestricted use, distribution, and reproduction in any medium, provided you give appropriate credit to the original author(s) and the source, provide a link to the Creative Commons license, and indicate if changes were made. The Creative Commons Public Domain Dedication waiver (http://creativecommons.org/publicdomain/zero/1.0/) applies to the data made available in this article, unless otherwise stated. 